\title{
Communication of Leadership and Group Conformity in Community Forest Management
}

\author{
Ike Rosmanita $^{1^{*}}$, Sarwititi Sarwoprasodjo ${ }^{2}$, Rina Mardiana ${ }^{2}$ \\ ${ }^{1}$ Postgraduate IPB University, Jl. Raya Darmaga, Gedung Sekolah Pascasarjana IPB, Kampus IPB \\ Darmaga Bogor 16680 - West Java, Indonesia \\ ${ }^{2}$ SKPM Department - FEMA IPB, Wing 1 - Level 5, Jalan Kamper, Kampus IPB Darmaga Bogor 16680 \\ - West Java, Indonesia
}

Received: 13 July 2020; Revised: 15 December 2020; Accepted: 18 February 2021

\begin{abstract}
The utilization of forest areas, especially in production forest areas managed by Perhutani, provides benefits to communities around the forest. The Collaborative Forest Management Program (PHBM) is supposed to improve community welfare and forest sustainability. Studies on the environment or forest area, group conformity (adjustment), and environmental values used by farmer groups in forest management practices can be analyzed using environment communication. The purpose of this research: Profile Mitra Tani Sejahtera group of forest village community associations (PMDH); Analyze relationship characteristics (cohesiveness and style of leadership) between forest management behavior of farmer groups; Analyze relationship conformity between forest management behavior farmer group; and Analyze environment values with forest management behavior. This research was conducted at the Mitra Tani Sejahtera group in Kediri. This study had 100 respondents using a random sampling system. Sampling from population data begins with determining the sample size using the Slovin formula. Data collection was carried out using questionnaires and closed interviews, and FGD. Data analysis used the Pearson correlation test to determine the relationship between variables. The results showed that the Pearson correlation coefficient between the cohesiveness and forest guarding behavior was .549**. There is a correlation between cohesiveness and forest protection behavior of 0.549 . leadership style related to community behavior in protecting the forest by $.245^{* *}$. The Result shows is a relationship between group characteristics (cohesiveness and leadership style) with the practices of maintaining forest security because of the sense of kinship in the group and a democratic leadership style. Conformity has a relationship with practices maintaining forest security because it complies with the rules made by Perhutani. Environmental values have a relationship with management forest security behavior because of a sense of cooperation within the group.
\end{abstract}

Keywords: PMDH; environment; communication; conformity; leadership

\section{How to cite:}

Rosmanita, I., Sarwoprasodjo, S., \& Mardiana, R. (2021). Communication of Leadership and Group Conformity in Community Forest Management. HABITAT, 32(1), 37-46. https://doi.org/10.21776/ub.habitat.2021.032.1.5

\section{Introduction}

Several parties have used forest areas to meet the needs of forest communities for economic improvement, including Perhutani. Permadi (2016) stated that Perum Perhutani has rights to forest resources through three leading roles: forest land, forestry companies, and forest conservation institutions. The program carried out by Perhutani is the Joint Community Forest

*Corressponding author

E-mail: ikerosmanita@gmail.com
Management (PHBM) to improve community welfare.

Research result Bahruzin et al. (2014)shows that the CBFM system's application has an impact on improving household economic conditions by contributing $52 \%$ to $85 \%$ of total income, improving forest ecological conditions, and reducing forest disturbance, and improving hydrological conditions. In line with research resultsKusno et al. (2017), PHBM can increase income with an average income of farmers per hectare per planting season per Rp year. 23,800,333 Besides, the PHBM program can provide jobs for communities around forests 
In the current condition, there are still many obstacles or problems in implementing PHBM that occur in the field. Problems that still occur and are the cause of the unsuccessful CBFM include four aspects, namely 1) problems with forest farmer groups, 2) problems related to the environment, 3) problems from policy aspects, and 4) issues related to stakeholders. (Sinabutar et al., (2014); Sutrisno, (2012); Ifrisala et al., (2016); Hidayat, (2014)). According to many forest farmer communities who do not clearly understand PHBM itself, the involvement or participation of the community is still low in the group aspect. The slow flow of communication between institutions and between members of community groups in conveying information, access to information, and a willingness to be "empowered," especially in efforts to increase productivity and increase community creativity(Wahanisa, 2015).

Rosyadi \& Sobandi (2014) stated that the cooperative relationship between Perhutani and the community was degraded because many people took the role of workers, not as decisionmakers in forest resource management. Also, support from stakeholders is still low. Policies are still centralized so that the narrative and boundaries are still not well socialized, affirming forest areas are only for administrative fulfillment(Sinabutar et al., 2014). This then raises problems in the environment as ignorance or insufficient knowledge and inadequate support from related parties. Dewi (2018) states that the poor and poorly educated conditions of the forest surrounding communities have caused the community to carry out forest encroachment, which impacts forest destruction.

Many of the people who plant plants are not under the area's condition, and the existing forest is dominated by stands that are considered unimportant (Hidayat, 2014). Another trigger for social forestry (PHBM) is not optimal due to socio-economic aspects, namely the community's low motivation and perception towards the benefits of the forest itself and people who are still encroaching forest areas.

Such problems must be resolved immediately, considering the many benefits from CBFM that the community can feel. Herutomo (2013) states that the community will feel they own the forest or conserve the forest if the community can feel the positive impact of forest management to change their mindset that the forest needs to be preserved.
One way to raise public awareness in environmental management is environmental communication. Flor and Cangara (2018) state that environmental communication is a new study that talks a lot about environmental problems, especially the relationship between humans and their natural surroundings, in a logical manner.

Environmental communication serves as a means of coordination and synchronization in community-based sustainable forest management. Research by Octavianti and Arifin (2017) states that participatory development communication can be done for forest conservation and development. The success in carrying out PHBM activities, of course, must be supported by forest farmers who must obey and follow the rules in the management of PHBM, such as the use of areas for planting, selecting planting locations, maintaining forest security, and forest preservation.

Sugihen et al. (2015) stated the conformity made by farmers because they hold traditional rules or values that apply in community life in managing existing forest land. Forest farmers adjust to their behavior or actions per group norms or rules to achieve sustainable CBFM management. Therefore, it is necessary to conduct a study on environmental communication, which includes conformity, group characteristics, and environmental values, which are expected to protect the forest environment from remaining sustainable.

Therefore, this study aims at 1) the group profile of Mitra Tani Sejahtera Forest Village Community Association (PMDH), 2) to analyze the relationship between the characteristics (cohesiveness and leadership style) of farmer groups with forest management behavior, 3) to analyze the relationship between farmer group conformity and behavior. forest management and 4) to analyze environmental values with forest management behavior.

Therefore, this study aims at

1. The group profile of Mitra Tani Sejahtera Forest Village Community Association (PMDH),

2. To analyze the relationship between the characteristics (cohesiveness and leadership style) of farmer groups with forest management behavior,

3. To analyze the relationship between farmer group conformity and behavior. forest management and 
4. To analyze environmental values with forest management behavior

\section{Research Methods}

This research is descriptive correlational. The research location is in Sempu Village, Ngancar District, Kediri Regency, East Java Province. Determination of the research location was done by random sampling. Data collection was carried out in October-December 2019. The population in this study were all farmers who were members of the Mitra Tani Sejahtera Community Association (PMDH), with 1038 people. A sample of 100 individuals was taken based on the results of calculations using the Slovin formula from this population. This study uses primary data and secondary data. Primary data were obtained from respondents using interview techniques using questionnaires and direct observation. Secondary data were obtained from village potential data, research journals, theses, and scientific writings related to research. Data analysis of the relationship between group characteristics, conformity, and environmental values with environmental management behavior using Pearson's correlation test using SPSS (quantitative analysis) and descriptive analysis (qualitative analysis).

\section{Results and Discussion}

\section{a. Profile of PMDH Mitra Tani Sejahtera}

Forest management with the community is carried out by Perum Perhutani Kesatuan Pemangkuan Hutan (KPH) X with the Forest Village Community Association in forestry partnership cooperation. Forestry partnership cooperation is one of the community empowerment activities in utilizing the Perum Perhutani area for forestry plant cultivation, seasonal crop cultivation, under-standing plant cultivation, fodder, fruits, silvopasture, and water use and ecotourism. This activity is expected to optimize the potential of land in the Perum Perhutani area.

The partnership between Perhutani Corporation and the community must be carried out according to the rules. The expected goals can be realized; namely, the forest is maintained, and the community is prosperous. Perum Perhutani, in this case, has the authority to determine the land to cooperate, determine the design of the cropping pattern, provide social guidance and guidance to $\mathrm{PMDH}$, and supervise and secure the partnership area. Meanwhile, PMDH conducts supervision and security of forestry plants in the Perum Perhutani area and provides intercropping plant seeds.

Rules that are prohibited or not allowed for People who are members of PMDH include using forestry partnerships for loan collateral, transferring cultivated land, stealing wood, cutting down forests, burning forest areas, increasing arable areas, abandoning cultivated land for two years, and renting and selling arable land locations. If the PMDH member commits the violation, he will be subject to sanctions, among others, being expelled from the PMDH member, being punished following the applicable laws and regulations, and terminating the agreement.

Other rules are related to planting time between groups and Perhutani, including pre-park, contract period, and under-standing land use period (PLDT). The pre-planting period is used by PMDH, which will manage the Perhutani land that has just been cut (utilized for six months). During the pre-planting period, the community will plant horticultural crops (vegetables). This is done because the land is still not covered by Perhutani core plants so that horticultural crops can grow well. After the pre-planting period continues with a contract period, the community (PMDH members) can manage Perhutani land for two years. At this time, the community was encouraged to plant corn and pineapple crops. After the contract period ended, several group members continued cooperating with Perhutani with a land-use system understanding. At this time, many people continued to plant corn or pineapple crops.

Interestingly, in community cooperation, it is divided into small groups consisting of 5 group members. Determination of members groups based on closeness to residence or kinship. Each group gets cultivated land, which must be processed according to the agreed rules. The process of determining the location of cultivated land is carried out by lottery system by Perhutani and representatives from the group leader. Each group gets a cultivated land area of 10 meters $\mathrm{x}$ 100 meters or only manages 2 meters x $100 \mathrm{~m}$ of land per person.

The cultivated land is not too vast, making some of the community not implement the rules according to the agreement where many of them "sell" the land. The community not managing the land includes scarce land; it wastes time, energy, and money if it is managed. The land's location 
and the conditions of the land that are not fertile are reasons for them to cultivate themselves or "sell" to others. Usually, there is already a cultivated broker who "enters" the group to sell their cultivated land during the drawing process. These land brokers include rich people in the village or outside the village. Apart from being sold to a broker, the cultivated land can be sold to other members who want to work on it or other people outside the group. The selling price depends on the location and soil fertility obtained during the distribution process.

Some group members still manage their land even though the area received is not large. This is because farmers obey the rules and are afraid of the sanctions given. Also, if the land is managed correctly, it can meet daily needs.

\section{b. Relationship characteristics \\ (cohesiveness and leadership style) of farmer groups with forest management behavior}

Cohesivity is the degree of attraction felt by individuals towards a group. Group cohesion is a force that encourages group members to stay in the group and prevents them from leaving the group. The percentage of group member cohesiveness can be seen in table 1 . The cohesiveness level of most of the farmer groups is moderate at $63 \%$ or classified as moderate.

Table 1. The percentage level of PMDH Mitra Tani Sejahtera group cohesiveness

\begin{tabular}{ll}
\hline Cohesivity level & $\begin{array}{l}\text { Persentase } \\
(\mathbf{\%})\end{array}$ \\
\hline Group & \\
Low & 0 \\
Moderate & 63 \\
High & 37 \\
\hline Total & $\mathbf{1 0 0}$ \\
\hline
\end{tabular}

Small group members were divided based on proximity to home and kinship. This makes the relationships within the group more closely. Farmers get many benefits by joining the group, as other group members can be relied upon when farmers have problems with land management. Farmers can also exchange ideas and ask other members for advice. This is because the group is a source of information and a feeling of comfort and pleasure.

The cohesiveness of group members who can use agricultural land with the PHBM scheme creates conditions the forest is better preserved. According to Magdalena (2013), An essential component in forest management and protection is cohesiveness. The existence of various kinds of interests between young people, the elderly, aristocrats, and ordinary people and between economic needs and environmental sustainability are successful accommodation in an agreement to defend the forest.

Leadership style is a leader's behavior that describes the philosophy, skills, traits, and attitudes to influence those under him (Utaminingsih, 2014). In table 2, it can be seen that the democratic leadership style most liked by group members is $55 \%$, the free control leadership style is $45 \%$ disagree. The authoritarian style is $54 \%$ strongly disagree. Based on interviews with respondents, group members were always involved, and the PMDH group carried out the activities.

Tabel 2. Percentage of leadership styles

\begin{tabular}{llllll}
\hline No. & Leadership Style & STS & TS & S & SS \\
\hline 1 & Laissez-faire & 27 & 45 & 25 & 3 \\
2 & Authoritarian & 54 & 43 & 3 & 0 \\
3 & Democracy & 0 & 1 & 55 & 44 \\
\hline
\end{tabular}

Farmers or group members are invited to a meeting in determining or formulating activities within the group. Based on the interview results, the results of the meeting decisions submitted by the group leader must be obeyed by group members because they are based on mutual agreement. The PMDH leader or chairperson's attitude who is willing to listen and deliberate in determining decisions makes him respected and listened to when giving directions and explanations or information related to forest management. According to Wardani (2012), a leader who commits is a leader whom his group members respect to encourage group members' participation in forest management.

A farmer group is an organization or a forum for farmers to exchange opinions, give suggestions, and even make decisions. The Group Chair culturally invites all group members to negotiate and deliberate in solving a problem or making a decision. The group leader is also a role model or an example for members where the group leader often patrols, manages land obtained well, and does not commit forest destruction or disappointing behavior. The group leader is close to each member without being directly involved in any event in the community. The members very like a leader like this.

The Pearson correlation test results using SPSS, the relationship between group 
characteristics and forest management behavior can be seen in table 3 .

Table 3. Pearson Correlation Test for group characteristics with forest management behavior

\begin{tabular}{llr}
\hline \multicolumn{1}{c}{ Variable } & \multicolumn{2}{c}{ Pearson Correlation Value } \\
\hline Agricultural land & Pearson Correlation & $-.199^{*}$ \\
use cohesiveness & Sig. (1-tailed) & .023 \\
& $\mathrm{~N}$ & 100 \\
Cohesivity to & Pearson Correlation & $.549^{* *}$ \\
protect the forest & Sig. (1-tailed) & .000 \\
& $\mathrm{~N}$ & 100 \\
Leadership style & Pearson Correlation & .023 \\
of agricultural & Sig. (1-tailed) & .411 \\
land use & $\mathrm{N}$ & 100 \\
Leadership style & Pearson Correlation & $.245^{* *}$ \\
guarding the & Sig. (1-tailed) & .007 \\
forest & & 100 \\
& $\mathrm{~N}$ & \\
\hline
\end{tabular}
characteristics (cohesiveness) and agricultural land use behavior has a value of Pearson's correlation coefficient is 0.199 or sufficient because it is at a value of $>0-0.25$. One star sign (*) means a significant correlation at a significance level of 0.05 . The more cohesion of a group, the higher the behavior of group members in agricultural land use. Meanwhile, the Pearson correlation coefficient between the cohesiveness variable and forest protection behavior is $.549 * *$. This means a correlation between cohesiveness and forest guarding behavior of 0.549 or strong because it is in a value of $0.5-0.75$. Two stars $(* *)$ means a significant correlation at a significance level of 0.01 . This shows that cohesiveness can make people protect the forest well. Research thing. Magdalena, (2013) Five factors that influence the community in enacting customary forest management laws include cohesiveness, close kinship, support from various parties, clarity of forest rights, transparency, and accountability, especially finance. Based on the Pearson correlation test results, the leadership style related to community behavior in protecting the forest was .245. The community or group maintains forest security because of the excellent example set by the group leader.

\section{c. The relationship between conformity and forest management behavior}

Conformity is a change or adjustment of behavior or belief towards group norms resulting from real, imagined, or perceived social pressure. In this study, observations were made to determine group conformity in agricultural land use and protecting forests. The conformity measurement can be seen from the 7 statement items. The results of the percentage of respondents can be seen in Table 4.

Group members still listen to other people's advice in agricultural cultivation by $77 \%$. Community knowledge about farming methods is still lacking, so they are open to receiving suggestions and input from any agricultural cultivation party. Besides, some group members expect training to be carried out by related agencies to improve their farming skills or skills.

The social value of the sempu village community is still high, and this is shown by the group members as much as $73 \%$ will avoid conflict if there is a debate on the use of agricultural land. One example is that group members voluntarily and voluntarily give the land to be cultivated to other group members, rather than going into trouble in land management.

As many as $39 \%$ of members agree that they still follow family traditions in agricultural cultivation. This shows that people's knowledge about farming methods still relies on an agricultural system passed down from generation to generation by their families.

Group members agree as much as $40 \%$ of decisions regarding cultivation depend on other group members. This is because the farmer feels he doesn't know and doesn't want to argue with other members. As many as $41 \%$ of group members are very easily influenced by charismatic people $(41 \%)$ and change their opinion because of the invitation of the chairman / other members of $44 \%$. A charismatic person is considered to have more knowledge and can convey information well to farmers. Farmers change their opinion because of the chairman or other members' invitation because they are not sure of their knowledge or lack of confidence. This shows that the community still tends to rely on other people's opinions on agricultural land use, namely $35 \%$ strongly agree.

In the aspect of agricultural land use, the conformity of group members is based on 1) imitating other dominant behavior, 2) following group members, 3) relying on other people's suggestions, and 4) being easily persuaded. 
Table 4. Percentage of respondents according to conformity in agricultural land use

\begin{tabular}{|c|c|c|c|c|c|}
\hline No. & Pernyataan & STS & TS & $\mathbf{S}$ & SS \\
\hline 1 & $\begin{array}{l}\text { Listen to } \\
\text { advice in } \\
\text { agricultural } \\
\text { cultivation }\end{array}$ & 3 & 20 & 29 & 48 \\
\hline 2 & $\begin{array}{l}\text { Avoid } \\
\text { conflict } \\
\text { rather than } \\
\text { defend } \\
\text { arguments } \\
\text { in } \\
\text { agricultural } \\
\text { cultivation }\end{array}$ & 3 & 24 & 34 & 39 \\
\hline 3 & $\begin{array}{l}\text { Following } \\
\text { family } \\
\text { traditions in } \\
\text { agricultural } \\
\text { cultivation }\end{array}$ & 1 & 30 & 39 & 30 \\
\hline 4 & $\begin{array}{l}\text { The } \\
\text { management } \\
\text { of the } \\
\text { cultivation } \\
\text { was decided } \\
\text { by friends }\end{array}$ & 3 & 26 & 40 & 31 \\
\hline 5 & $\begin{array}{l}\text { A } \\
\text { charismatic } \\
\text { person can } \\
\text { influence } \\
\text { agricultural } \\
\text { cultivation }\end{array}$ & 4 & 22 & 33 & 41 \\
\hline 6 & $\begin{array}{l}\text { Changing } \\
\text { opinions in } \\
\text { agricultural } \\
\text { cultivation } \\
\text { because of } \\
\text { the } \\
\text { invitation of } \\
\text { the group } \\
\text { leader / } \\
\text { member }\end{array}$ & 5 & 20 & 31 & 44 \\
\hline \multirow[t]{3}{*}{7} & $\begin{array}{l}\text { Relying on } \\
\text { other } \\
\text { people's } \\
\text { opinions in } \\
\text { agricultural } \\
\text { cultivation }\end{array}$ & 20 & 26 & 19 & 35 \\
\hline & Total & 39 & 168 & 225 & 268 \\
\hline & Average & 5.57 & 24.00 & 32.14 & 38.29 \\
\hline
\end{tabular}

Note:

STS = Strongly Disagree, $\mathrm{TS}=$ Disagree, $\mathrm{S}=$ Agree, SS= Strongly Agree
The conformity of group members in protecting the forest can be seen in table 5. Group members disagree as much as $46 \%$ listening to other people's advice to protect the forest. This shows that the members have their way of protecting the forest, such as not burning in the land preparation process. Also, the community has awareness, such as conducting patrols on their own without coercion from other parties. Group members prefer to avoid conflict, namely $46 \%$ with other group members, to protect the forest. If there are group members who do not patrol, other group members can only remind them and not forcefully invite them. This was done to avoid conflict in determining patrol schedules.

Table 5. Percentage of respondents according to conformity in protecting forests

\begin{tabular}{|c|c|c|c|c|c|}
\hline No. & Question & STS & TS & $\mathbf{S}$ & SS \\
\hline 1 & $\begin{array}{l}\text { Listen to advice } \\
\text { on protecting the } \\
\text { forest }\end{array}$ & 11 & 46 & 34 & 9 \\
\hline 2 & $\begin{array}{l}\text { Avoiding conflict } \\
\text { rather than } \\
\text { defending } \\
\text { arguments for } \\
\text { protecting forests }\end{array}$ & 2 & 25 & 46 & 27 \\
\hline 3 & $\begin{array}{l}\text { Following family } \\
\text { traditions in } \\
\text { protecting the } \\
\text { forest }\end{array}$ & 9 & 28 & 49 & 14 \\
\hline 4 & $\begin{array}{l}\text { The forest guard } \\
\text { arrangement was } \\
\text { decided by } \\
\text { friends }\end{array}$ & 4 & 24 & 52 & 20 \\
\hline 5 & $\begin{array}{l}\text { A charismatic } \\
\text { person can } \\
\text { influence in } \\
\text { protecting the } \\
\text { forest }\end{array}$ & 13 & 46 & 28 & 13 \\
\hline 6 & $\begin{array}{l}\text { Changed opinion } \\
\text { in protecting the } \\
\text { forest because of } \\
\text { the invitation of } \\
\text { the group leader / } \\
\text { member }\end{array}$ & 4 & 34 & 44 & 18 \\
\hline 7 & $\begin{array}{l}\text { Rely on other } \\
\text { people's opinions } \\
\text { in protecting the } \\
\text { forest }\end{array}$ & 24 & 43 & 31 & 2 \\
\hline & $\begin{array}{l}\text { Total } \\
\text { Note }\end{array}$ & $\begin{array}{l}67 \\
9.57\end{array}$ & $\begin{array}{l}246 \\
35.14\end{array}$ & $\begin{array}{l}284 \\
40.57\end{array}$ & $\begin{array}{l}103 \\
14.71\end{array}$ \\
\hline
\end{tabular}


The patrol system or guarding the forest carried out by group members still mostly follows family traditions; $49 \%$ agree, namely joint patrols. $52 \%$ of the group members agreed that other members determined the schedule. Other people who have charismatic characteristics are not able to influence group members to protect the forest. According to the community, charismatic people do not necessarily say anything about protecting the forest that is already a good example. However, if a group member/group leader asks for the patrol, $44 \%$ of the members will follow because they think they have set a good example. Besides, 34\% of the group members would not take part in the patrol or guard the forest because, according to them, there were officers already patrolling.

The level of group conformity in forest management can be seen in table 6 . The level of conformity of group members in using land for agriculture and protecting forests is high at $57 \%$. This shows that group members make adjustments to existing group rules. Most of the group members obey the rules made by PMDH, following the agreement with Perum Perhutani. This is under the research resultsSugihen et al. (2015), namely, farmers' conformity because they hold the rules or traditional values that apply in social life in managing existing forest lands.

Table 6. The level of conformity of PMDH Mitra Tani Sejahtera

\begin{tabular}{ll}
\hline Conformity & Persentase (\%) \\
\hline Level of Conformity & \\
Low & 0 \\
Moderate & 43 \\
High & 57 \\
\hline Total & $\mathbf{1 0 0}$ \\
\hline
\end{tabular}

The conformity made by group members in land management is based on 1) the desire not to have conflicts between members, 2) the limited knowledge they have and 3) a high sense of kinship, and 4) fear of sanctions.

The Pearson correlation test results for conformity with forest management behavior can be seen in table 7. The results of the Pearson correlation test for conformity with land use behavior are $-.188 *$. This means a negative correlation between the conformity variable and the behavior of .188 , or the correlation is very weak at a value $>0-0.25$. Meanwhile, the Pearson correlation coefficient for conformity with forest protection behavior is $.253 * *$. This means that there is a correlation between the conformity variable and the behavior of protecting the forest. This is by the research results by Setyowati and Nugroho (2015), which states that people who are on the edge of the forest conform to protecting forests in the Perhutani area because it is per the agreement and the community gets an award.

Table 7. Pearson Correlation Test for conformity with forest management behavior

\begin{tabular}{llr}
\hline Variable & \multicolumn{2}{c}{ Pearson Correlation } \\
\hline Agricultural land & Pearson Correlation & $-.188^{*}$ \\
use conformity & Sig. (1-tailed) & .031 \\
& $\mathrm{~N}$ & 100 \\
Conformity & Pearson Correlation & $.253^{* *}$ \\
guarding the & Sig. (1-tailed) & .006 \\
forest & $\mathrm{N}$ & 100 \\
\hline
\end{tabular}

\section{d. Relationship between environmental values and forest management behavior}

Environmental value is the culture that each individual has as a belief in the environment related to the formation of attitudes to protect the environment (Gumelar, 2016). The environmental values observed in this study include egoistic, altruistic, and biophysical. Egoistic values are characterized by group members' value orientation based on their egos, prioritizing personal interests with considerations on the advantages and disadvantages of carrying out management practices for themselves. Altruistic value orientation is the willingness of a person in a group to benefit other group members in managing CBFM. Biosfirical value orientation is a value that emphasizes the preservation of nature, fellow humans, and other living things.

The percentage of environmental values can be seen in Table 8 . The table shows the low value of the Egoistic environment of the PMDH Mitra Tani Sejahtera group, which is $63 \%$, which means that group members do not feel more concerned with their interests in CBFM management. This shows that group members are bound by PMDH rules with Perhutani and are aware of the risks. However, there is still $37 \%$ egoistic value because some group members still clear land by burning. The reasons for farmers to keep clearing land by burning, among others, are comfortable, fast, cheap, and the land becomes more fertile. Hadiwijoyo et al. (2017) state that the land's preparation by burning because the yield of rice will be more. 
Table 8. Percentage of respondents according to the environmental values of PMDH Mitra Tani Sejahtera

\begin{tabular}{ll}
\hline Environmental Value & Persentase (\%) \\
\hline Egoistic & \\
Low & 63 \\
Moderate & 0 \\
High & 37 \\
Total & 100 \\
Altruistic & \\
Low & 35 \\
Moderate & 0 \\
High & 65 \\
Total & 100 \\
Biosfiric & \\
Low & 8 \\
Moderate & 1 \\
High & 91 \\
\hline Total & $\mathbf{1 0 0}$ \\
\hline
\end{tabular}

The altruistic environment value is high by $65 \%$. This shows that the PMDH group cares about other group members. This is because group members still adhere to cooperation and care (sharing land) with other group members in the management of PHBM. One of the activities carried out by the group is to form a team for the division of work areas (distribution of land plots) and a schedule for forest patrols. Research results Tjatjo et al. (2015) states that the community agroforestry development pattern is included in the Social Value (altruistic) category because of the agroforestry farming pattern developed, concern for solidarity the development of groups or community members by forming farmer working groups in opening new land.

The value of the biosphere environment is high at $91 \%$. This shows that group members are very concerned about the environment in managing CBFM-based forests. This is because PMDH group members realize the importance of forests being protected so that economic needs are maintained, and environmental quality can be maintained. Currently, people are starting to realize that if the forest is not protected, it will cause a temperature change, and the community will have difficulty getting clean water.

The results of the Pearson correlation test between environmental values and forest management behavior can be seen in table 9. The correlation test results show that environmental values are related to people's behavior in protecting forests. According to research Tjatjo et al. (2015), there is a relationship between environmental values (altruistic values) with the Namo village community's behavior in managing land with agroforestry systems.

Table 9. Pearson Correlation Test of environmental values with forest management behavior

\begin{tabular}{llr}
\hline Variable & Pearson Correlation Value \\
\hline The environmental & Pearson Correlation & -.019 \\
value of & Sig. (1-tailed) & .427 \\
$\begin{array}{l}\text { agricultural land } \\
\text { use }\end{array}$ & $\mathrm{N}$ & 100 \\
$\begin{array}{l}\text { Environmental } \\
\text { value to protect the } \\
\text { forest }\end{array}$ & Pearson Correlation & $.221^{*}$ \\
\hline
\end{tabular}

\section{Conclusion}

The conclusions of this study are as follows:

1. High cohesiveness and democratic leadership style enable the community to carry out forest management well. Cohesiveness is closely related to community behavior in protecting the forest because of the group's close kinship.

2. The conformity made by group members in land management is based on 1) the desire not to have conflicts between members, 2) the limited knowledge they have and 3) a high sense of kinship, and 4) fear of sanctions. In this study, conformity is closely related to community behavior in protecting the forest because it follows the rules of Perhutani.

3. Group members in forest management develop altruistic environmental values because of cooperation. Environmental values are related to forest protection behavior.

Suggestions from this research include the following:

1. The community or PMDH Mitra Tani Sejahtera group needs to openly evaluate the implementation of PHBM every year to know the group's condition. This needs to be done in order to find a better CBFM management system.

2. PMDH members need to receive training in agriculture, specifically in understanding agriculture. This needs to be done because the cultivation system understands different from the agricultural system in general. 


\section{References}

Bahruzin, B., Hidayat, A., \& Kumala Putri, E. I. (2014). Analisis Efektivitas Kelembagaan Pengelolaan Hutan Bersama Masyarakat (PHBM) di KPH Bandung Utara Jawa Barat. Journal of Agriculture, Resource and Environmental Economics, 1(1), 1-11. https://doi.org/10.29244/jaree.v1i1.11282

Dewi, I. N. (2018). Kemiskinan Masyarakat Sekitar Hutan dan Program Perhutanan Sosial. Info Teknis Eboni (15) 2: 65 - 77

Damayantanti, P. T. (2011). Upaya Pelestarian Hutan Melalui Pengelolaan Sumber- Daya Hutan Bersama Masyarakat. Jurnal Komunitas, 3(1), 70-82.

Floor AF dan Cangara H. 2018. Komunikasi Lingkungan. Kencana: Yogyakarta

Gumelar, G. (2016). Nilai Lingkungan dan Sikap Ramah Lingkungan Pada Warga Jakarta Di Pemukiman Kumuh Environmental Values and Pro Environmental Attitude In Jakarta' s Slum Residencies . Jurnal Psikologi, 12(1), 39-46.

Hadiwijoyo, E., Saharjo, B. H., \& Putra, I. (2017). Kearifan Lokal Masyarakat Dayak Ngaju Di Kalimantan Tengah Dalam Melakukan Penyiapan Lahan Dengan Pembakaran. Jurnal Silvikultur Tropika, 08(1), 1-8.

Herutomo, C. (2013). Komunikasi Lingkungan dalam Mengembangkan Hutan Berkelanjutan. Acta DiurnA, 9(2), 37-48. http://komunikasi.unsoed.ac.id/sites/defaul t/files/Komunikasi Lingkungan dalam Mengembangkan Hutan Berkelanjutan Ch Herutomo.pdf

Hidayat, S. (2014). ( Vegetation Conditions in Sesaot Protected Forest, West Lombok, West Nusa Tenggara, as Basic Information in Forest Management ). Jurnal Penelitian Kehutanan Wallacea, 3(2), 97-105.

Ifrisala, L. O., Kartodihardjo, H., \& Bramasto Nugroho. (2016). Implementation of Hutan Tanaman Rakyat Policy in Muna District Southeast Sulawesi. Jurnal Silvikultur Tropika, 07(3), 159-164.

Kusno, K., Wulandari, L., \& Suminartika, E. (2017). Program Pengelolaan Hutan Bersama Masyarakat. Jurnal Agribisnis Dan Sosial Ekonomi Pertanian, 2(1), 253 261. http://jurnal.unpad.ac.id/agricore/article/vi ew/15075

Magdalena, M. (2013). Peran Hukum Adat Dalam Pengelolaan Dan Perlindungan Hutan Di Desa Sesaot, Nusa Tenggara Barat Dan Desa Setulang, Kalimantan Timur. Jurnal Penelitian Sosial Dan Ekonomi Kehutanan, 10(2),

110-121. https://doi.org/10.20886/jsek.2013.10.2.11 $0-121$

Permadi, I. (2016). Perlindungan Hukum Terhadap Petani Penggarap Tanah Negara Milik Perum Perhutani. Arena Hukum, 9(2), 225-250.

https://doi.org/10.21776/ub.arenahukum.20 16.00902 .5

Rosyadi, S., \& Sobandi, K. R. (2014). Relasi Kuasa Antara Perhutani Dan Masyarakat Dalam Pengelolaan Sumberdaya Hutan Di Banyumas: Kepentingan Bisnis Vs Community Empowerment. Komunitas: International Journal of Indonesian Society and Culture, 6(1), 47-56. https://doi.org/10.15294/komunitas.v6i1.29 39

Sinabutar, P., Nugroho, B., Kartodihardjo, H., \& Darusman, D. (2014). Reforming the Gazettment of State Forest Area in Riau Province. Jurnal Manajemen Hutan Tropika (Journal of Tropical Forest Management), 20(3), 179-186. https://doi.org/10.7226/jtfm.20.3.179

Sugihen, B., Gani, D., Sumardjo, S., \& Yumi, Y. (2015). Local Institutions Support in Farmerss Learning for Implementing Sustainable Private Forest Management in Gunung Kidul District, DI Yogyakarta Province and Wonogiri District in Central Java Province. Jurnal Penyuluhan, 8(2).

Sutrisno, A. (2012). Analisis Persepsi Dan Motivasi Petani Terhadap Manfaat Sumberdaya Hutan Lindung Pulau Tarakan. Sorot, $\quad 7(2), \quad 128$. https://doi.org/10.31258/sorot.7.2.2007

Tjatjo, N. T., Basir, M., \& Umar, H. (2015). Karakteristik Pola Agroforestri Masyarakat Di Sekitar Hutan Desa Namo Kecamatan Kulawi Kabupaten Sigi. Jurnal Sains Dan Teknologi Tadulako, 4(3), 55-64.

Wahanisa, R. (2015). Model Pengelolaan Hutan Bersama Masyarakat (PHBM) Rofi 
Wahanisa Fakultas Hukum Universitas Negeri Semarang E-mail : 4(2), 416-438.

Winata, A. D. I., \& Yuliana, E. (2012). Tingkat Partisipasi Petani Hutan dalam Program Pengelolaan Hutan Bersama Masyarakat ( PHBM ) Perhutani. XXVIII(1), 65-76. 